\title{
Parents' Positive Role in Students' Learning Process at Ishik University Preparatory School
}

\author{
Mustafa Tosun \\ Department of Languages, Ishik University, Suleimani, Iraq \\ E-mail: mustafa.tosun@ishik.edu.iq
}

Doi:10.7575/aiac.alls.v.6n.4p.203

Received: 10/04/2015

URL: http://dx.doi.org/10.7575/aiac.alls.v.6n.4p.203

Accepted: 19/06/2015

\begin{abstract}
The reason that motivated me to initiate this writing is to emphasize the deficiency in the motivation and unwillingness of university youth cause of the parents approach toward the education at preparatory school. Moreover, my aim is to declare realistic suggestions about the issue with the help of observations that have been gained during the profession of teaching. These observations urged me to intensify on the act of the parents and their relations with guidance unit at preparatory school. This study was conducted to attract the significance of parents involvement and its yield at prepschool.
\end{abstract}

Keywords: Motivation, guidance unit, parents role

\section{Introduction}

In motivation the act of parents is quite substantial. If parents care about their college children, they make more educational achievements than those who are disregarded, but most of the parents usually do not concentrate on this issue. Owing to this conduct, it is getting hard to succeed. Looking at the success and motivation problems you might say the main reason is the attitude of parents at Preparatory school of Ishik University. Although students' IQ level is not low and they are able to learn easily also they even have little moral problems they feel difficulty in learning. We should draw a right conclusion to find the reason if 91 students from 253 cannot finish the preparatory school on the level of pre-intermediate. The number of the students that enrolled for preparatory school was 253 in the academic year of 2013-2014. The level of the first coming students was A1. It is the beginning level according to Common European Framework of Reference for Languages (CEFR) standards. In my research I desire to make clear the students` results by the help of data collecting table and questionnaire besides, I wish to find responses for the question of what extent parents are interested in the guidance unit. Data collecting table which indicates students' level after graduation of preparatory school has been given in the part of appendix. More over the chart that was prepared by the evaluating unit would support us in the following parts of the article.

\section{Literature Review}

The aim of this observational research article is to clarify the positive role of the parents for EFL leaners by the help of three components in turns: problems, proposals which date back to different social science articles and a questionnaire that was conducted by teachers at preparatory school. Depending on the introductory sentence will be given several retrieved expressions. For instance, Robinson-Wright also points out that many students at two-year colleges are the first generation in their families to attend college. As a result, their parents want and need more information to understand the mechanics of higher education (Benbow, 2012). Due to giving example, parents play a vital role in the education of their child, whatever child's age is, (either he read in college or in school). This phrase also supports one of my questionnaire questions of informing the parents at preparatory school. Having an involved parent can be a key to student's success in college (Foley, 2008). It is a saying that you could be a shoulder to lean when your child stumbles. Clearly, parents have a role to play throughout the entirety of their children's educational careers. But as time goes on, that role needs to become more advisory (Benbow, 2012). It is clear that initial year (as preparatory school) parents 'role of involvement more significant than the subsequent years. The parental involvement factor was positively related to gains in sociopolitical awareness for freshmen. (Harper, Sax, Wolf 2012). As the part of the preparatory school, the unit of guidance should get involved the parents in order that they will develop students emotional and academic achievement. Involved, supportive parents set their children up for emotional and academic success (Kelmon, 2013). In the light of educators' theories which mentioned above we could analyze the article by means of indicating several problems. This analysis supports our hypothesis and helps to find real responses for drawing conclusion.

\subsection{Problem of the statement}

Providing objective is the most significant matter that influences learning process. The present studies were initially carried out with an aim to explore possible variations in long term socialization goals of mother in terms of their educational background (Yağmurlu, Çttlak, Dost\&Leyendecker, 2009). Because of the literacy level of parents is too 
low they don't know what kind of objective will provide their own children. Besides they are not able to keep in touch with the unit of guidance in preparatory school. Especially teenagers usually separate from their parents because of the psychological problems and reduced sharing in the time of study. The lack of the parents in education is the second inevitable reason for learning. Education levels of family influence on the social status of children. It is considered that the more education mothers level have the better communication they have. (Sarıaya, Ogelman, 2011). It is the cause of being failed with the cultural deprivation of parents. Moreover, they are not aware of how to educate their children adequately.

The higher parents education level develop, the better student's academic achievement rises. On the other hand, it has been well established that parent-child interactions in early life form the foundation for the child's social and emotional development (Tremblay, 2010). Due to these well-educated families establish good contact with their children and they increase their motivation of achievement. Parental educational level is an important predictor of children's educational and behavioral outcomes (Davis\&Kean, 2005). If the parents' education level is low, it influences the atmosphere inside the family and prevents the mental development. Not only the mental ability and social life, but also the parents' attitude effect student's success. When we look at the education level of parents, they are categorized as both successful and unsuccessful. It is obvious that the level of education which belongs to parents of unsuccessful students is quiet low. In this context lack of reading habits of the parents also is significant for student's development. One of the most problems with the recent increase in the use of technology; children are getting addicted to digital world. The global changings in mobile devices all around the world caused global digitalization on young generation. Unwillingly they are born as a digital native. According to some scholars they are called net generation or Google generation (McNeill, Ming \& Gosper 2011). And parents have insufficient knowledge of behaviour about this issue. When we look from the general perspective of parents they might consider so: "when we were children, we suffered a lot, we had not such beautiful electronic devices, and we wish our children have everything they need" so parents` feelings of compassion let children misuse gadgets and technological facilities. As a result of this their children start living in a virtual world and nearly all relations are broken. In that time parents understand their mistakes but nowhere to back. Upbringing child in a materialistic world is also one of the influencing factors. Some parents of the children are more interested in what they do as a materialistic character, but they ignore the fact that who they are. yet loving and supportive parents can also use material goods to express their love, paving the way for their children to grow up to be more likely than others to admire people with expensive possessions and judge success by the kinds of things people own (Richins \&Chaplin, 2015). They have spent their physical and spiritual strength for their children's grades and achievements but they have been back on the emotional needs. In this context parents face with the irresponsible and reckless children instead of responsible. It causes to lose motivation of the students. If we make it clear we might give you a few examples: First, students are not able to dream about the experience and hardness of real life. Second, let's say he or she has got a career with the help of his relatives. So we face with a bad-tempered, non-productive, nonintegrated type of people. At this point one of the parents especially father tries to be in this issue but his acquisition of education has not been quite enough. As a result both students and parents are getting non-achiever. Imposing a sense of responsibility affects for the achievement of the students. Recent researches have been made about the senses of responsibility indicate that the embryo in the womb is feeling and sharing the sense of mother (Döner, 2014).If we start the issue with this point, it is clear how important giving responsibility in the period of adolescence and childhood. In this age parents are forced to understand how to approach the students. Although parents are being polite to children with their attitudes it is generally misunderstood and returned to parents as a reaction. In case they do not to take into account generation gap, students are becoming hypocrite like they are loyal dog at home and attacker dog outside.

Certainly this kind of attitude triggers lie after that you may meet the miserable generations with no motivation. Parents' enforcement in the choice of department for students is unavoidable factor before the academic year. In the first year of college, after starting the department of parents preferred, the number of the students are not pretty much who fall in to unhappiness even desire to change their universities. These kinds of students neglect all kind of learning skills because they don't have any sort of hope that will motivate them. One of the biggest problems with children in today' society is youth apathy (Gratz, 2006). Sometimes you might face with different ones as if they seem to be expected that their parents will help them. Also most of them think that they need only diploma nothing else.

\section{Methods}

\subsection{Participants}

Twenty lecturers of Ishik University Preparatory School participated in filling the questionnaire. They were chosen deliberately because they have been working for 5 years as a lecturer at preparatory school. The number of the male lecturers was 15 and the number of the female lecturers was 5.

\subsection{Measures}

I obtained the data from the figure which was shown at the part of findings, appendix and questionnaire that was conducted. I listed six items on the questionnaire. In this questionnaire I used the dichotomous method questions with the help of yes/no/not sure. According to the results of the questionnaire 14 of the 15 male lecturers have complied with the necessity of guidance unit and involving parents to the education of preparatory school. 4 of 5 female lecturers have declared positive words about the establishing of guidance unit and involving parents as the female lecturers. 


\section{Findings}

The following figure is presented to clarify the observations.

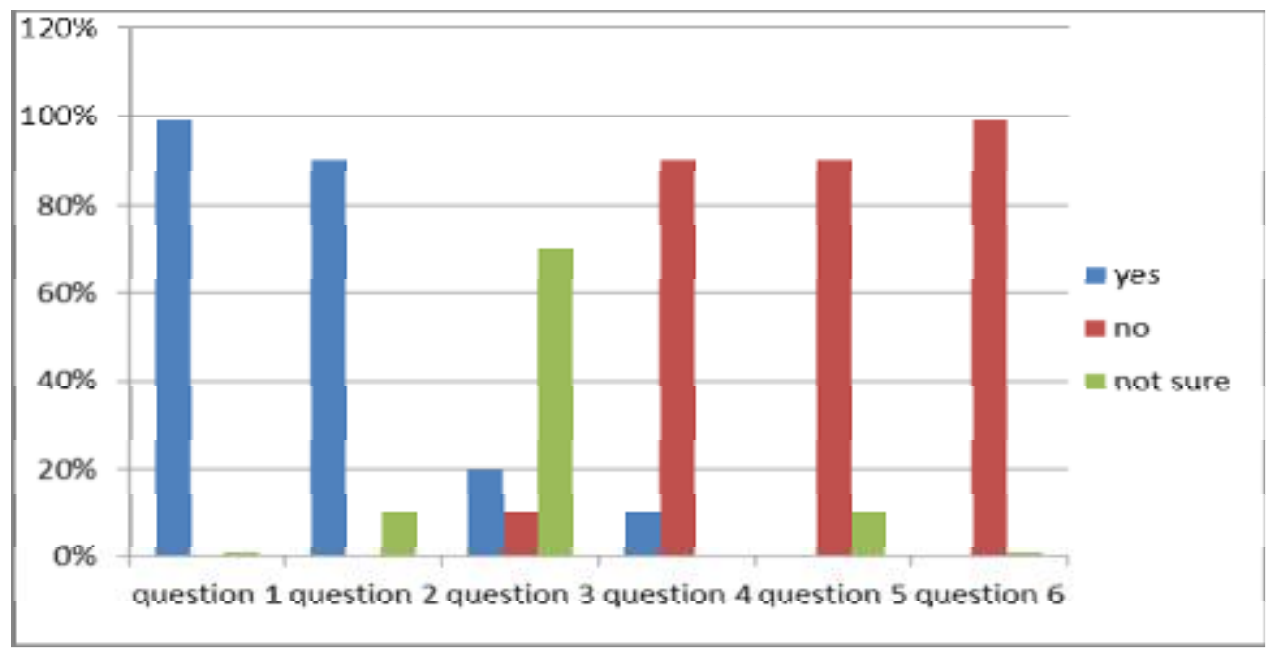

According to results of the study it is determined that first, preparatory school should include or establish guidance unit for parents. Second, guidance unit ought to reach the parents and give information to some extend about the attitude of students. More over guidance unit should not give information about the function of preparatory school and use of technology including internet based programs unless they demand. Parents should keep in touch with guidance unit of preparatory school all the time. It may come to mind a question like this. Whether parents must interfere the students issue or it can be solved by students alone. This is a disputable question for different group of people and most of our colleagues who have been working as lecturers of preparatory school prefer to study both with students and parents. Although university students are older than 18 years they don't know or not to be informed about their future career. As result of this they have been exposed to lack of motivation. Like a ship in a huge Ocean that doesn't know where to go. Cooperation of parents has been more effective in preparatory school than that of the other departments and some actions should be fulfilled as keeping in touch with parents in necessary conditions. The distinguishing part of the preparatory school from elders is it has been an accustomed period for students. Furthermore, it should be given adaptation education both parents and students at preparatory school in order that students may continue their career with no hesitation. As my research has been done during two academic years in the Region of Kurdistan, Iraq, I noticed that the more parents knew about children, the more successful students would be.

\section{Conclusion \& Suggestions}

In the end of this study, I came to conclusion that both parents and lecturers should collaborate to improve students' motivation. Also, following suggestions which are given to both parents and lecturers support my idea.

1. Providing objective: Having an education process which provides a qualified education that is appropriate for university students' expectations and goals may also serve to meet the needs and expectations of the society (Şahin, Zoraloğlu \& Firat, 2011). One of the biggest problems of the students in this age is aimlessness. Because of this they are not able to think and read the actual problems of the world. Students are influenced negatively or positively according to the aim provided. These objectives might be about faith, consciousness of history, future generations etc. Also they should include vision.

2. It should be done more researches on concrete concepts: Chosen aim and vision ought to create concrete concepts because commitment to concrete concepts is reduced in the development cycle of the students and people. During this age, spiritual sciences are perceived much more than the other social sciences students gain. Adolescents are known to understand the metaphor better. "Such as young people, people of the most dynamic, most utopian, most romantic, most fearless, perhaps the most productive period of investigation; the exploitation of its energetic structure, is almost debt on behalf of humanity" (Tuncay, 2000). The impact of concrete concept would be understood much pretty considering the events of ISIS how deceived the youth have been taken to the war. In addition, it reveals why we need to take care of young people much more.

3. Providing sensible devotion: Love is the first thing to be considered. It is certain that young man would sacrifice himself for his love and purpose and it is obvious that 'Lover and beloved adolescence' will obey (Çelegen, 1998). Parents attitude ought to be positive and affectionate if they want to have children's heart.

4. Incentives should be increased by taking advantage of the use of technology. Education policy makers, curriculum designers, academician should encourage the teachers to integrate them into their classes. Parents should be involved into the process (Pimmer, Pachler \& Attwell, 2010). Digital world that has to be tendency to increase in real life, especially mobile phones and tabs should be used as teaching materials with the application of having social infrastructure like Edmodo and Muddle etc.

5. Individual approaches should be used by teachers. So it's the teachers' duty to generate motivational strategies to keep the students motivated towards the foreign language (Koran, 2014) Teacher is not only the course teacher, but 
also he or she should be the students' teacher. It means in addition to teaching, as it was in the course teacher should try to be together with students with the help of social facilities at the university. At least teachers might drink tea, have lunch and find common interests with students. Besides in order to get more quality education, the possibilities of dormitory should be improved and prepared English language practising atmosphere by the guidance unit.

\section{References}

Benbow, C. (2012). Parents' role for college needs to be more advisory. Retrieved from https://my.vanderbilt.edu/camillabenbow/news/parents role for college needs to-be more advisory.

Foley, C. (2008). Family involvement can help with student's college success.

https:/enroll.iupui.edu/admissions/documents/presentations/family involvement.pdf.

Baskı, İ. (1998). Peygamberimiz Kadınlara Nasıl Davranırdı. Retrieved from http://www.ajansnigde.com/peygamberimiz-s-a-v-kadinlara-nasil-davranirdi-d73488.html

Davis-Kean, P. E. (2005). The influence of parent education and family income on child achievement: the indirect role of parental expectations and the home environment. Journal of family psychology, 19(2), 294.

Döner, A. (2014). Ergenlik dönemi yol haritası. Işık Yayıncılık Ticaret.

McNeill, M., Ming Diao, M., \& Gosper, M. (2011). Student uses of technology in learning: two lenses. Interactive Technology and Smart Education, 8(1), 5-17.

Gratz, J., Nation, S. O., Schools, S. O., \& Kurth-Schai, R. (2006). The Impact of Parents' Background on their Children's Education. Educational Studies, 268, 1-12.

Harper, C. E., Sax, L. J., \& Wolf, D. S. S. (2012). The Role of Parents in College Students' Sociopolitical Awareness, Academic, and Social Development. Journal of Student Affairs Research and Practice, 49(2), 137-156.

Kelmon, J. (2013). Great School. Retrieved from

http://webcache.googleusercontent.com/search?q=cache:abiRO5knUzYJ:blogs.greatschools.org/greatschoolsblog.

Koran, S. (2015). Analyzing EFL Teachers' Initial Job Motivation and Factors Effecting Their Motivation in Fezalar Educational Institutions in Iraq. Advances in Language and Literary Studies, 6(1), 72-80.

Pimmer, C., Pachler, N., \& Attwell, G. (2010). Towards work-based mobile learning: what we can learn from the fields of work-based learning and mobile learning. International journal of mobile and blended learning, 2(4), 1-18.

Richins, M. L., \& Chaplin, L. N. (2015). Material Parenting: How the Use of Goods in Parenting Fosters Materialism in the Next Generation. Journal of Consumer Research, 41(6), 1333-1357.

Sarikaya, H. E., \& Ogelman, H. G. (2013). Okul Öncesi Eğitimi Almiş Çocuklarin Akran İlişkileri Değişkenlerinin 5 Ve 6 Yaşta İncelenmesi: İki Yillik Boylamsal Çalişma. Turkish Studies - International Periodical For The Languages, Literature and History of Turkish or Turkic, 8(8),1859-1871

Şahin, İ., Zoraloğlu, Y. R., \& Fırat, N. Ş. (2011). Üniversite Öğrencilerinin Yaşam Amaçları, Eğitsel Hedefleri Üniversite Öğreniminden Beklentileri ve Memnuniyet Durumları. Kuram ve Uygulamada Eğitim Yönetimi Dergisi, 17(3), 429-452.

Tuncay, S. (2011). Türkiye’de gençlik sorunlarının psikolojik boyutu. Muğla Sitki Koçman Üniversitesi Sosyal Bilimler Ensitüsü Dergisi,1(1).

Tremblay, R. E. (2010). Developmental origins of disruptive behaviour problems: the 'original sin'hypothesis, epigenetics and their consequences for prevention. Journal of Child Psychology and Psychiatry, 51(4), 341-367.

Yağmurlu, B., Çıtlak, B., Dost, A., \& Leyendecker, B. (2009). Child socialization goals of Turkish mothers: An investigation of education related within-culture variation. Turkish Journal of Psychology, 24(63), 16-19.

\section{Appendix}

\begin{tabular}{lccc}
\hline & Number & ratio & Cerf \\
\hline Students at the beginning of the year & 253 & $100 \%$ & $\mathrm{~A} 1$ \\
Failed by attendance & 25 & $9.8 \%$ & $\mathrm{~A} 2$ \\
Failed by general average & 33 & $13.04 \%$ & $\mathrm{~A} 2$ \\
Failed by exam & 58 & $22.9 \%$ & $\mathrm{~A} 2$ \\
Total students fail & 91 & $35 . \%$ & $\mathrm{~A} 2$ \\
Total students success & & $65 \%$ & $\mathrm{~B} 2$ \\
The level in the beginning & & & $\mathrm{A} 1$ \\
Required mark in the end & & & $\mathrm{B} 2 / \mathrm{C} 1$ \\
\hline
\end{tabular}




\section{Questionnaire}

1. Is it necessary to establish guidance unit at preparatory school?
a) Yes
b) no
c) not sure

2. Do you think if the guidance unit should collaborate with the parents of preparatory school students?

a) Yes b) no c) not sure

3. Do you think if the guidance unit should collaborate only with the students of Ishik University Preparatory School?
a) Yes
b) no
c) not sure

4. Should the guidance unit give information about proceedings (progress) to the parents?

$\begin{array}{lll}\text { a) Yes b) no } & \text { c) not sure }\end{array}$

5. Do all of the matters which we mentioned above depend on the students' profile?
a) Yes b) no
c) not sure

6. Do you think if the guidance unit should collaborate with only the students that were forced to study in the departments with parents' pressure?
a) Yes
b) no
c) not sure 